\title{
Experimental Study on Concrete Incorporating Date Seed as Partial Replacement of Coarse Aggregates
}

\author{
Ali Raza, PALH \\ Department of Civil Engineering, Mehran UET, Shaheed Zulfiqar Ali Bhutto Campus \\ Khairpur Mir's, Sindh, Pakistan \\ aliraza.ce16@muetkhp.edu.pk \\ Sajjad Ali, MANGI \\ Department of Civil Engineering, Mehran UET, Shaheed Zulfiqar Ali Bhutto Campus \\ Khairpur Mir's, Sindh, Pakistan \\ sajjad.nec@gmail.com \\ Masroor Ahmed, ODHO \\ Department of Civil Engineering, Mehran UET, Shaheed Zulfiqar Ali Bhutto Campus \\ Khairpur Mir's, Sindh, Pakistan \\ Odhomasroor1234@gmail.com \\ Ayaz Ahmed, KALHORO \\ Department of Civil Engineering, Mehran UET, Shaheed Zulfiqar Ali Bhutto Campus \\ Khairpur Mir's, Sindh, Pakistan \\ ayazkalhoro1@gmail.com \\ Sehrish, HAFEEZ \\ Department of Civil Engineering Technology, Benazir Bhutto Shaheed University of \\ Technology and Skill Development (BBSUTSD) Khairpur Mirs, Sindh, Pakistan \\ Sehrish.ce@gmail.com
}

\begin{abstract}
In the world the most widely used material is concrete. It is the most important and second number consumable substance after water in the world and plays a vital role in infrastructure and private buildings construction. Various waste materials like coconut shells, date seeds, rubber seed shell, palm kernel shells, etc. were studied by various researchers and replaced for coarse aggregate in concrete making. This study attempted to use Date Seeds as a fractional replacement with coarse aggregate in the concrete. The design mix ratio 1:2:4 of binding substance cement, fine aggregate and coarse aggregate/date seeds were investigated in this study work only. Total 24 number of Cylinders of diameter and height of $4{ }^{\prime} \times 8$ ' were made. The $0 \%, 2 \%, 3 \%$ and $4 \%$ of Date Seed were replaced with Coarse aggregate. The physical properties of Date Seed, fine aggregate and coarse aggregate were find out. The specific gravity of DS was calculated 1.0 and water absorption was $24 \%$ for 48 hours. The bulk density value was $843 \mathrm{~kg} / \mathrm{m}^{3}$ which was greater than the previous research works, the fineness modulus of DS, CA \& FA were 1.7, 2.18 and 3.08, respectively. Another important thing which was observed during this work that the DS ws expanding on the absorption of water. The workability of concrete was decreasing as the total surface area of coarser particles was increased. The results of compressive strengths were quite satisfied at $2 \%$ \& $3 \%$ replacement.
\end{abstract}

\section{Keywords}

Date Seed, lightweight Concrete, Compressive Strength and Partial Replacement.

\section{Introduction}

In the world the most widely used material is concrete. It is the second greatest-consumed ingredient after water in the world and plays a vital role in infrastructure and private buildings construction, it is a material used in construction projects by many countries and its requirement is increasing day by [1]. Concrete is consisted with three major constituents: cementitious material (lime or cement) aggregate (rock, sand, or gravel) and water. Cement, generally grinded in powder form, 
and is acting like a binding ingredient when mixed-up with aggregate and water. The mixture formed or mixed concrete will be changed and harden into the durable and stable material by filling the void spaces among the particles of aggregate [1], [2]. The availability of concrete constituents is decreasing so there is a need to replace them with some other materials like agro-wastes such as Rubber seed shell, coconut shell and Date Seeds etc. and researches are needed to for their behaviour under loading conditions [3]. Evaluation of the performance of concrete containing date seeds as a replacement of coarse aggregates, the depletion and increased demand creates a need for research and innovation for economic and environmentally friendly materials [4]. The present and future demand for the construction industry are construction materials which are lightweight, durable, economic and environmentally sustainable because there is need for such materials that provide lowincome houses for developing and those countries where other materials are not abundantly available and for these countries, it is difficult to arrange the classical or conventional building materials (steel and concrete) because their price is very high and away from their approach [1]. The concrete word is derived from the Latin word "concretus" (means condensed or compact) from "con" and "crescere" (meaning to grow). The major constituent of concrete is a coarse aggregate which constitutes about 60 to $80 \%$ of volume and 70 to $85 \%$ by weight of concrete [5]. Waste materials like coconut shells [2], [6], date seeds [7], [8], [9], [10], rubber seed shell [11] [11], palm kernel shells [6], etc were studied by various researchers and replaced for coarse aggregate in concrete.

Date palm (Scientific name: Phoenix dactylifera $L$ ) is one of the essential crop in the arid regions that comes in the category of friuts. the fruit called "dates" are the major income source and food for residents and its product has great importance in various countries in which these fruits are cultivated, and have played significant roles in the society, economy and environment of those farmlands. Palm dates are yellow colour when raw and changing red to brown when bocoming ripe. It is nearly elongated spherical ellipsoid in shape. A hard seed has consisted of each Palm seed [12]. Coarse aggregates have a essential part in the subsequent practical properties of concrete [7].

In 2010 research in Libya was conducted on the durability of Date Seeds acting as lightweight concrete. In this study, several trial mixes were formed, and the satisfactory combinations were chosen. The optimum Date Seed concrete mixture selected was included with $500 \mathrm{~kg} / \mathrm{m}^{3}, 310 \mathrm{~kg} / \mathrm{m}^{3}$, $820 \mathrm{~kg} / \mathrm{m}^{3}$ of cement, Date Seed and sand, respectively. Superplasticizer of 1.5 litres per $100 \mathrm{~kg}$ of cement with water-cement ratio of 0.37 was used. The ratio of Cement: Sand: Date Seed by volume was corresponding to $1: 2.2: 1.50$ of fine and coarse aggregates occupying approximately 77 per cent of the entire volume of the date seed concrete [9]. In the study, two curing procedures were selected in-situ were considered. First involved $3 \& 7$ days curing in moist. Second, the site for exposure was free for solar radiation, wind and rainfall. The durability properties of concrete made from Date Seed at the ages of 28,56 and 90 days were determined through many tests in which sorptivity, water absorption water permeability and chloride penetration were included. The procedure that was adopted by Teo et al [13]. for lightweight concrete in the research investigated about oil palm shell has been followed.

The research investigated by Aka, Adamu, \& Nensok [8] [14] on the characteristics of durability of concrete formed with the date seed acting as a lightweight material [8] and Adefemi [7] on the suitability of date seed (DS) as lightweight aggregate material as full or partial replacement in production of concrete [7], these works were conducted in Nigeria. Physical and mechanical properties of Date Seed and Crushed Granite were compared after determining. Concrete mix design of ratio 1:2:4 \& 1:3:6 was explored. the total number of concrete cubes was 90 and their size as 150 $\times 150 \times 150 \mathrm{~mm}^{3}$ with different replacement by weight of Crushed Granite to Date Seed as 100:0, $75: 25,50: 50,25: 75$ and $0: 100$ to coarse aggregate were cast and for a maximum of 28 days were immersed in ordinary water and compressive strength test was conducted. The compressive strength test results showed that all the percentage replacement of Crushed Granite for Date Seed except $100 \%$ remained quite acceptable without any compromison in compressive strength for the two concrete mix ratios (1:2:4 and 1:3:6) requirements. The research resolved that date seed can partially be replaced and used with Crushed Granite in production of lightweight concrete where it is abundantly available and can be recommended as an replaceable material (fractional replacement) to CA. In physical properties, the specific gravity of DS was calculated as 1.39 , compacted bulk density value $526 \mathrm{~kg} / \mathrm{m}^{3}$, the loose bulk density was $462526 \mathrm{~kg} / \mathrm{m}^{3}$, water absorption percentage was 8.10 , also same properties were determined for crushed granite. In mechanical properties, the workability test, compressive strength and density tests were performed for a replaced percentage of date seed with coarse aggregate.

The same research work was also performed in India by Akib, Dipesh and Dinesh [10]. Physical and Mechanical properties of Date Seed were Determined and compared.The investigation on 324 cubes were explored on mix design $M_{20}, M_{25}$ and $M_{30}$ of concrete. The cubes of size 
$150 \times 150 \times 150 \mathrm{~mm}^{3}$ in the order $75: 25,80: 20,85: 15,90: 10,95: 05,100: 0$ by weight on different percentages of Coarse Aggregate to Date Seed was adopted. The cubes were cast and immersed in normal water for a maximum of 28 days for compressive strength test and submerged in $5 \%$ Hydro Chloric Acid $(\mathrm{HCl})$ with water for a maximum of 90 days in order to perform durability test. The durability and compressive strength test performed on the concrete samples showed that all the percentage replacement of Date Seed of $5 \%$ replacement for $M_{20}$ and $10 \%$ replacement for $M_{25}$ and $\mathrm{M}_{30}$ mix was fairly acceptable. The research concluded that $10 \%$ Date Seed can be used to replace Coarse Aggregate in the preparation of advanced mix design of concrete where it is plentifully accessible and can be suggested as an substitute material to coarse aggregate [10].

The physical properties result from past research works are shown in table 1 and workability test results in table 2 .

Table 1 : Physical properties of date seed from previous research

\begin{tabular}{cccc}
\hline References & Specific Gravity & Water Absorption (\%) & Bulk Density \\
\hline$[9]$ & 1.13 & $36 \%(24$ hours) & $584 \mathrm{~kg} / \mathrm{m}^{3}$ \\
{$[14]$} & 1.39 & $8.10 \%$ & $526 \mathrm{~kg} / \mathrm{m}^{3}$ \\
{$[7]$} & 1.39 & $8.10 \%$ & $526 \mathrm{~kg} / \mathrm{m}^{3}$ \\
{$[10]$} & 1.00 & $8.8 \%$ & $764 \mathrm{~kg} / \mathrm{m}^{3}$ \\
\hline
\end{tabular}

Table 2 : Workability in earlier findings [7]

\begin{tabular}{ccccc}
\hline S. No & $\begin{array}{c}\text { Concrete } \\
\text { Ratio }\end{array}$ & $\begin{array}{c}\text { Concrete sample (CG: } \\
\text { DS) }\end{array}$ & $\begin{array}{c}\text { Water- } \\
\text { cement ratio }\end{array}$ & $\begin{array}{c}\text { Slump value } \\
\text { (mm) }\end{array}$ \\
\hline 1 & & $100: 0$ & & 5 \\
2 & & $75: 25$ & & 6 \\
3 & $1: 2: 4$ & $50: 50$ & 0.6 & 6 \\
4 & & $25: 75$ & & 7 \\
5 & & $0: 100$ & & 8 \\
1 & & $100: 0$ & & 7 \\
2 & & $75: 25$ & 0.65 & 7 \\
3 & $1: 1.5: 3$ & $50: 50$ & & 7 \\
4 & & $25: 75$ & & 9 \\
5 & & $0: 100$ & & \\
\hline
\end{tabular}

1.1 Aim

To develop lightweight concrete containing date seed as a partial replacement of coarse aggregate for the concrete.

\subsection{Objective}

a) To determine the physical properties of materials (fine aggregate, coarse aggregates, and date seed).

b) To evaluate the workability of freshly mixed concrete and compressive strength of hardened concrete containing date seeds as a coarse aggregate.

c) To establish a relationship between density and strength of concrete contains date seeds and coarse aggregates.

\section{Materials and Research Methodology}

\subsection{Materials}

The ingredients of concrete used for this study were obtained within Khairpur Mir's in Sindh Province. Ordinary Portland Cement OPC (Power Brand) was used in the lab experiment, the fine aggregate used was got from the rocks located in Kot Banglo (Khairpur). It was sieved in the laboratory to remove coarser particles. Coarse aggregate was also purchased from the same place 
and date seeds were obtained in sufficient quantities from Pano Akil and Khairpur (famous for producing dates within the province). The DS collected, were washed and dried in sun for 20 days to decrease the moistness Normal water suitable for drinking was used for the research.

\subsection{Mix Proportion}

Batching operation by weight was used in this work. 1:2:4 ratio for the design mix of cement, fine aggregate and coarse aggregate (partially with DS) was selected and investigated. The watercement ratio $(\mathrm{w} / \mathrm{c})$ of 0.5 was used for a true mix. The material was calculated for 6 cylinders each time and was properly mixed for 5-7 minutes in machine mixer. Total 24 number of Cylinders of diameter and height of 4 ' $\times 8$ ' were adopted. The $0 \%, 2 \%, 3 \%$ and $4 \%$ of Date Seed were replaced with Coarse aggregate. The ratios of Coarse aggregate to Date Seed were (0:100), (2:98), (3:97) and (4:96).

\subsection{Casting}

The moulds of PVC pipe of 4 inches in diameter and 8 inches in height with a cap at the bottom were used. The moulds were correctly oiled. Workability of freshly mixed concrete was determined, and the concrete mix was poured thoroughly into the moulds of cylinders. The 6 Cylinders of each ratio DS: CA were cast and moulded after $24 \mathrm{hrs}$. out of which 3 were immersed in ordinary tap water for 7 days and 3 for 28 days. On completion of curing periods of $7 \& 28$ days, cylinders were dried at room temperature inside the lab for $2 \mathrm{hrs}$. the density of each cylinder was calculated before crushing. The cylinders were tested for the compressive strengths of per BS 1881: Part 116: (1983) specifications with the use of Technotest Compressive Testing Machine. The flow chart shown in the figure shows all the steps in research methodology. 


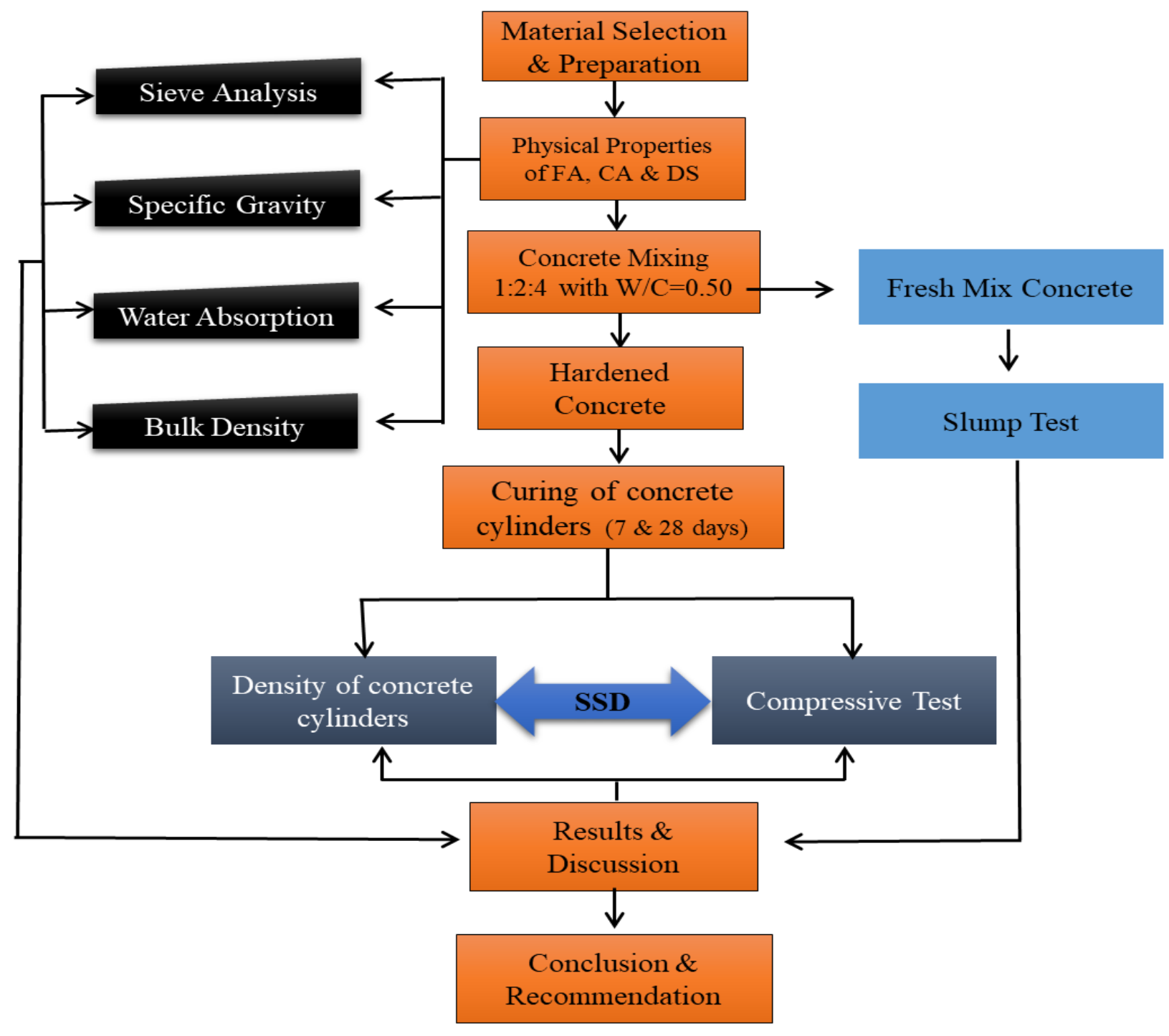

Figure 1: Flow Chart of Experimental Study

\section{Results and Discussion}

\subsection{Physical properties of materials used for research work.}

The bulk density test conducted on the samples chosen from materials used for the this study followed the requirements of ASTM C29 / C29M - 07. Bulk density of DS is $843 \mathrm{~kg} / \mathrm{m}^{3}$ within the range of lightweight aggregate $\left(1200 \mathrm{~kg} / \mathrm{m}^{3}\right.$ or less) hence it can be called as a lightweight material. The specific gravity of the materials was calculated according to ASTM C $127-88$ provisions. The specific gravity of date seed was obtained is 1.0, this value is less than given in Brooks and Neville [1]. The range for this value is between 2.6 to 2.7. The water absorption test was performed according to the provision of ASTM C $127-88$ and was found to be $24 \%$ which is excessively higher for good lightweight material. The sieve analysis of materials was determined according to (ASTM C 136-84a). The fineness modulus of DS is found to be 1.7 which is less than the values 2.6 to 3.5 . The results are shown in Table 3.

Table 3: Physical properties of FA, CA and DS

\begin{tabular}{ccccc}
\hline S. No. & Properties & \multicolumn{3}{c}{ Sample type and description } \\
\cline { 3 - 5 } & & FA & CA & DS \\
1 & Specific Gravity & 2.55 & 2.60 & 1.0 \\
2 & Fineness Modulus & 3.08 & 2.18 & 1.7 \\
& $($ FM) & & & \\
\hline
\end{tabular}




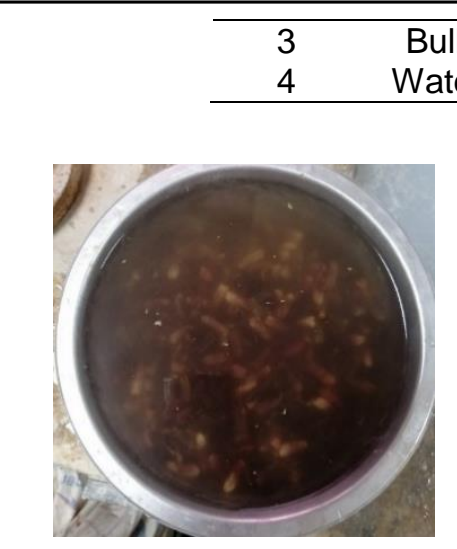

(a)

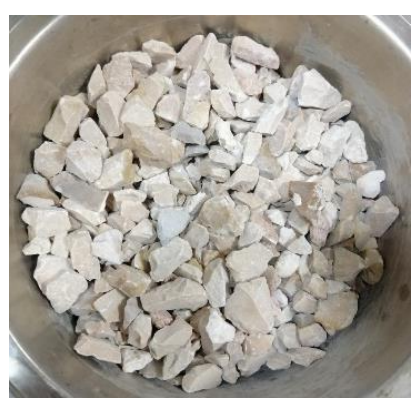

(b)

\begin{tabular}{lc}
1528 & 843 \\
0.76 & 24 \\
\hline
\end{tabular}

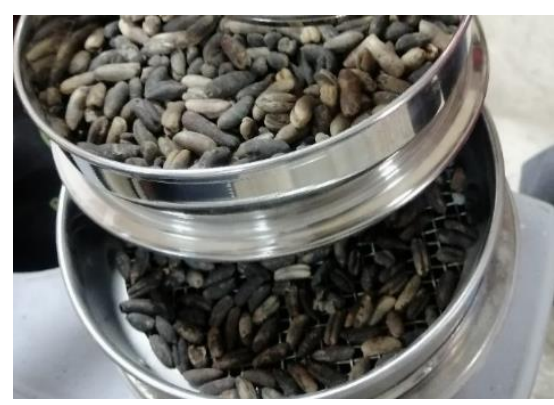

(c)

Figure 2: (a) Date seeds, (b) Coarse aggregates and (c) Sieve analysis of date seeds

\subsection{Workability (Slump Test)}

The workability was determined by performing a slump test under the ASTM C143-89a (ASTM international-2003). The results obtained are given in table 4 and figure 3 . From the calculated values it is clear that the workability of concrete is decreasing with increasing date seeds this is due to Absorption of water by DS and increase in the surface area of coarser particles.

Table 4: Slump test Values with $w / c=0.5$

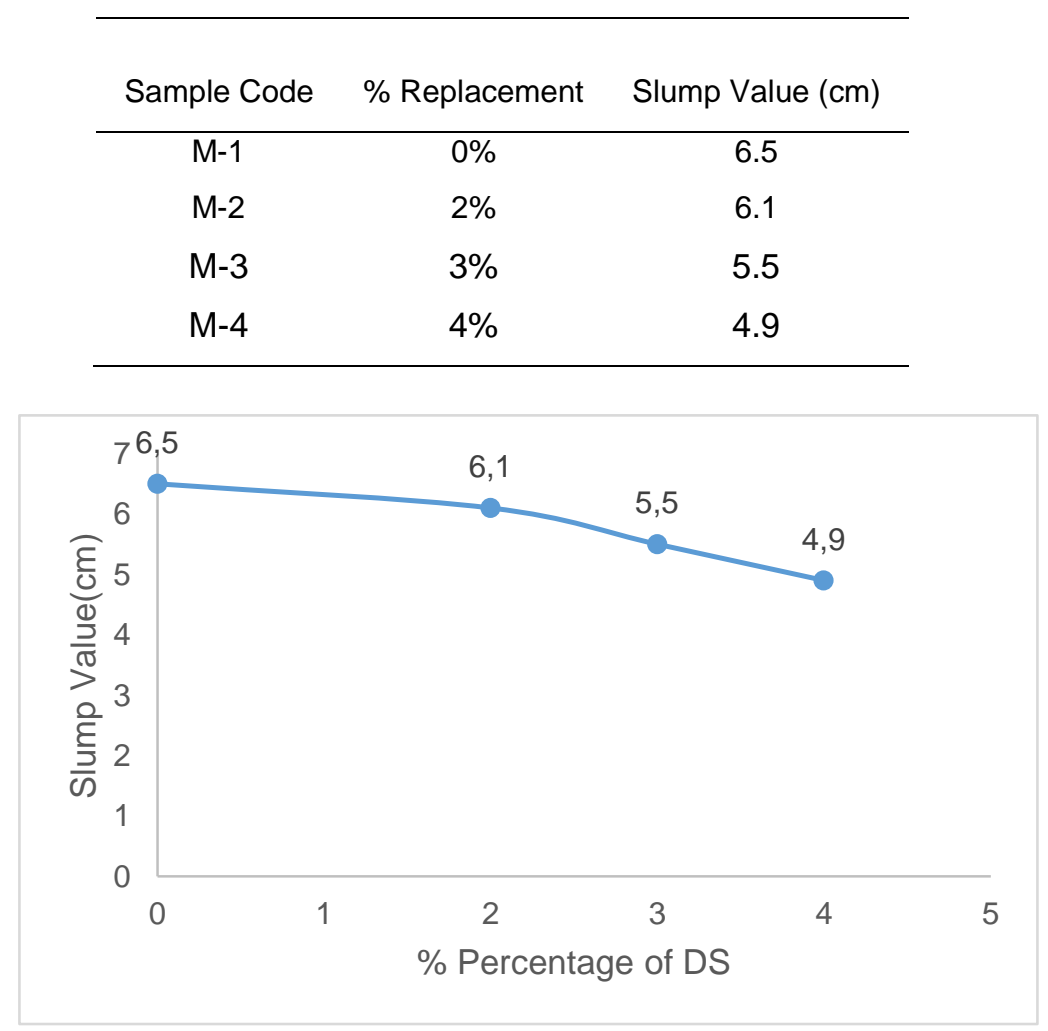

Figure 3 : Slump with different percentage (\%) of DS 


\subsection{Compressive Strength}

The Experimental study work was conducted on cylinders of for compressive strength by replacing coarse aggregates with date seed in concrete. The compressive test was performed on the compressive testing machine according to [15] to obtain the loss in the strength of concrete comprising date seed as shown in figure 4.

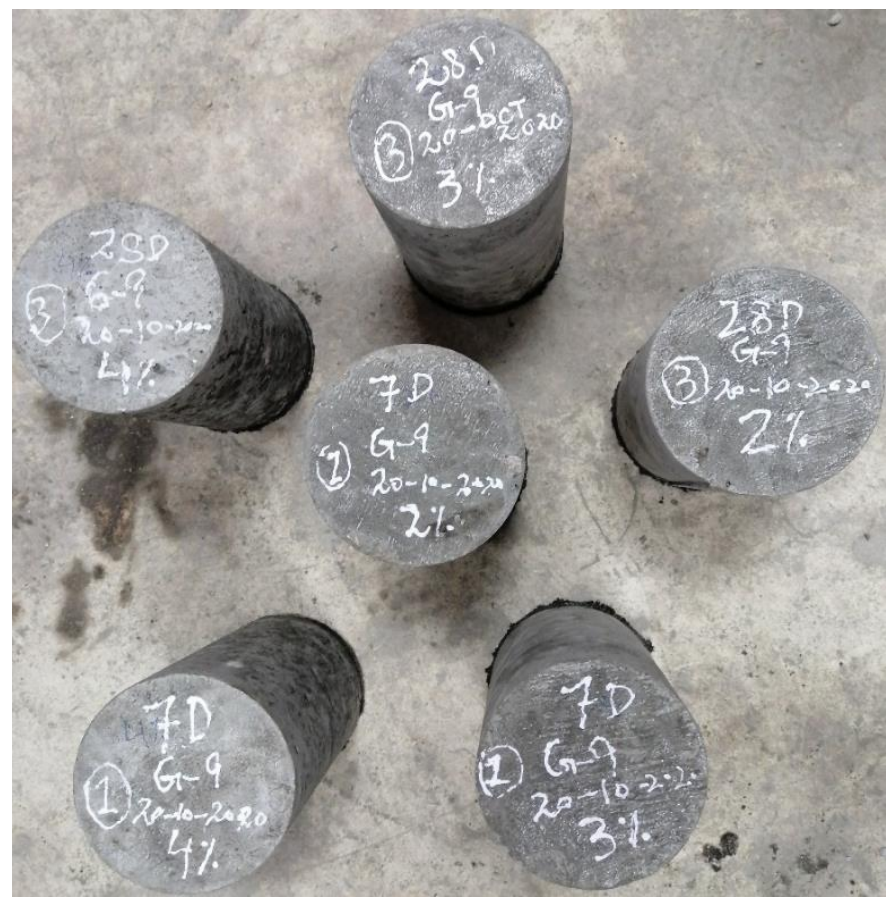

(a)

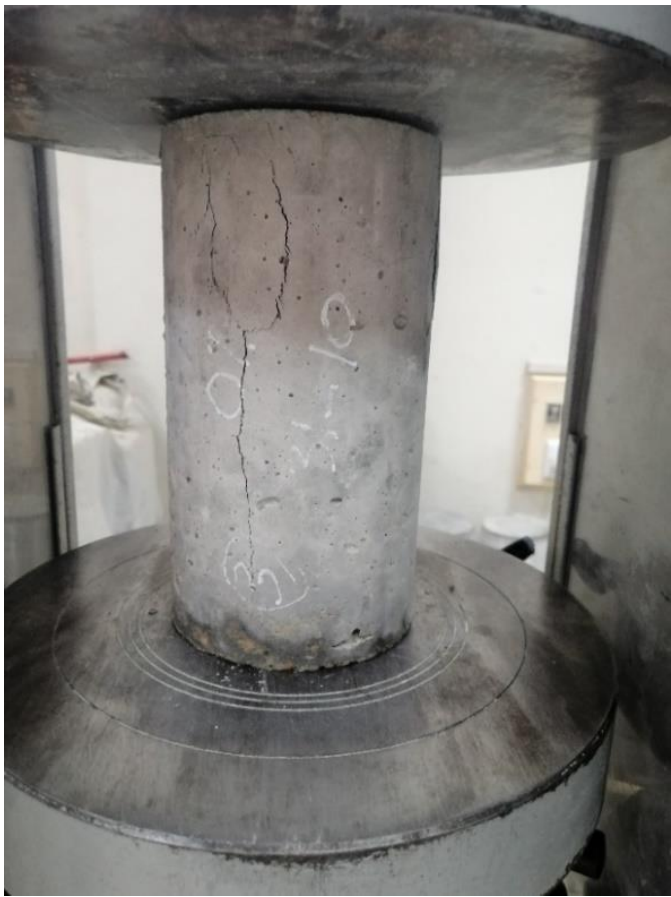

(b)

Figure 4: (a) Concrete cylinders casted for conducting research, (b) Compressive Strength Test

From the results (shown in table 5) it was finalized that the average values of compressive strength cylinders made-up of concrete were decreasing with the addition of date seed. The decreasing in strength is caused by the lightweight material date seed because it is round ellipsoid in shape with longitudinal cut up to $1 / 3^{\text {rd }}$ of its thickness. 
Table 5 : Average Compressive Strength results at $7 \& 28$ Days

\begin{tabular}{cccc}
\hline $\begin{array}{c}\text { Sample } \\
\text { Code }\end{array}$ & $\begin{array}{c}\% \\
\text { Replacement }\end{array}$ & $\begin{array}{c}\text { Average Strength } \\
(\mathbf{M P a}) \text { at 7 Days }\end{array}$ & $\begin{array}{c}\text { Average Strength } \\
(\mathbf{M P a}) \text { at 28 Days }\end{array}$ \\
\hline $\mathbf{M}-\mathbf{1}$ & $0 \%$ & 21.70 & 23.55 \\
$\mathbf{M}-\mathbf{2}$ & $2 \%$ & 17.41 & 20.87 \\
$\mathbf{M}-3$ & $3 \%$ & 14.73 & 16.28 \\
$\mathbf{M}-\mathbf{4}$ & $4 \%$ & 12.74 & 13.63 \\
\hline
\end{tabular}

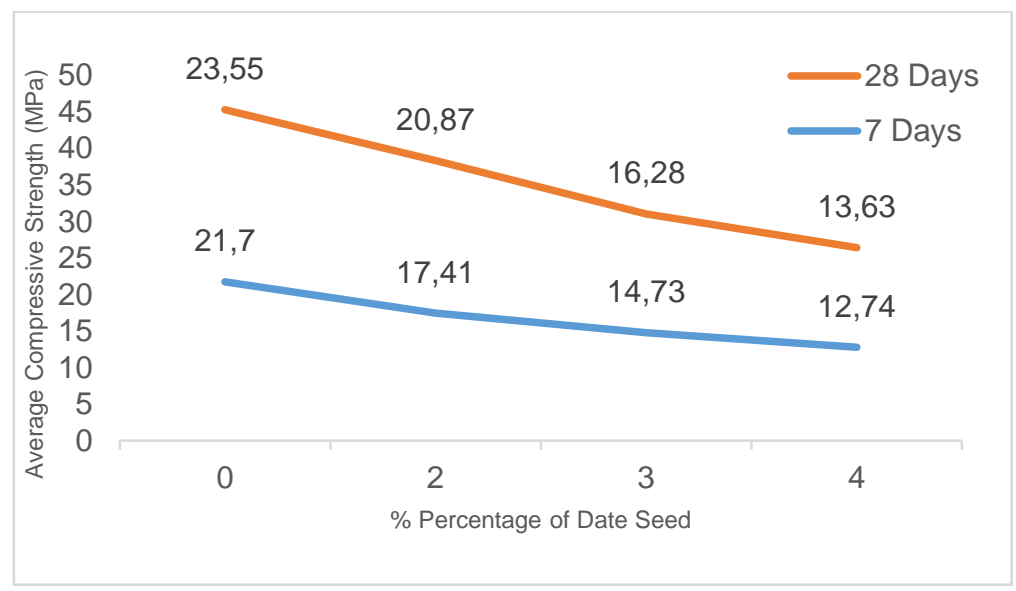

Figure 5 : Average Compressive Strength

The results of compressive strength at 7 and 28 days show that the more strength is obtained at 28 days curing in normal water but when more date seeds are replaced, the increase in strength is not linear to the results obtained at 7 days.

\subsection{Relationship between average density to the average compressive strength of concrete cylinders}

The density of hardened concrete cylinders was determined in accordance with ASTM-C64213 and the values are given in table 5 and table 6 at $7 \& 28$ days, respectively. The relationships between average density and average compressive strength are shown in figure 1 and 2 . The relationships show that the density and strength are decreasing with the addition of date seeds, when we go to replace more percentage the density will decrease, and concrete will become lightweight concrete, but the loss in compressive strength will certainly happen.

Table 6: Values of Average Bulk Density (SSD) and Average Compressive Strength at 7 Days

\begin{tabular}{cccc}
\hline $\begin{array}{l}\text { Sample } \\
\text { Code }\end{array}$ & $\begin{array}{c}\% \\
\text { Replacement }\end{array}$ & $\begin{array}{c}\text { Average Density } \\
\left(\mathrm{kg} / \mathrm{m}^{3}\right)\end{array}$ & $\begin{array}{c}\text { Average Strength } \\
\text { (MPa) }\end{array}$ \\
\hline $\mathbf{M}-1$ & $0 \%$ & 3026.07 & 21.70 \\
$\mathbf{M}-2$ & $2 \%$ & 2993.17 & 17.41 \\
$\mathbf{M}-3$ & $3 \%$ & 2980.44 & 14.73 \\
$\mathbf{M}-4$ & $4 \%$ & 2968.76 & 12.74 \\
\hline
\end{tabular}




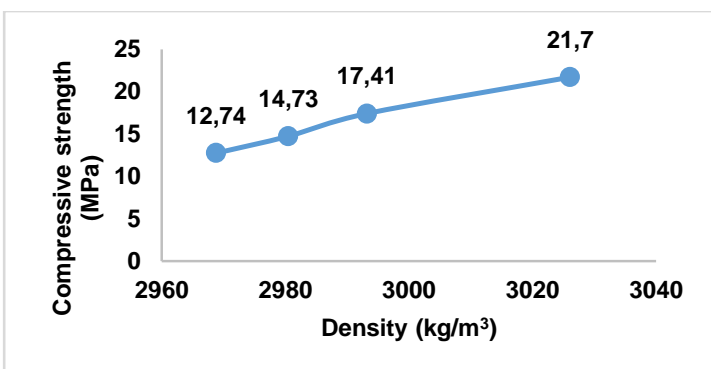

(a)

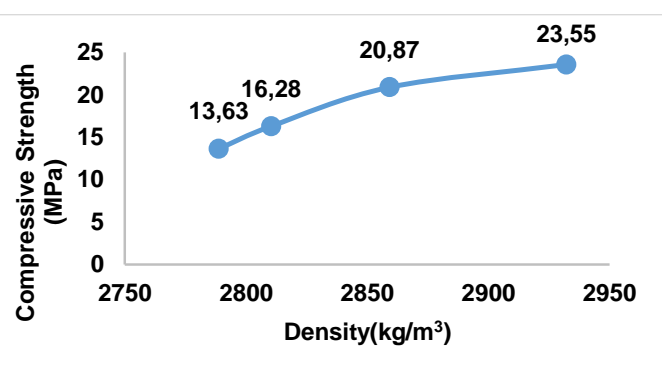

(b)

Figure 6: Relationship between density $\left(\mathrm{kg} / \mathrm{m}^{3}\right)$ \& compressive strength (MPa) at. (a) 7 days and (b) 28 days.

Table 7: Values of Average Bulk Density (SSD) and Average Compressive Strength at 28 Days

\begin{tabular}{cccc}
\hline $\begin{array}{c}\text { Sample } \\
\text { Code }\end{array}$ & $\begin{array}{c}\% \\
\text { Replacement }\end{array}$ & $\begin{array}{c}\text { Average Density } \\
\left(\mathrm{kg} / \mathrm{m}^{3}\right)\end{array}$ & $\begin{array}{c}\text { Average Strength } \\
\text { (MPa) }\end{array}$ \\
\hline $\mathbf{M}-\mathbf{1}$ & $0 \%$ & 2932.14 & 23.55 \\
$\mathbf{M}-\mathbf{2}$ & $2 \%$ & 2859.18 & 20.87 \\
$\mathbf{M}-3$ & $3 \%$ & 2810.34 & 16.28 \\
$\mathbf{M}-\mathbf{4}$ & $4 \%$ & 2788.76 & 13.63 \\
\hline
\end{tabular}

It was observed through the experimental investigations that the concrete strength was decreased with the addition of more amount of date seeds as a coarse aggregate replacement. However, more replacement causes reduction in density and ultimately delivered lightweight concrete but reduces the compressive strength of concrete. Thus, concrete containing date seeds as a coarse aggregate could be used for non-structural concrete buildings.

\section{Conclusion}

This study work of research was concluded to determination of physical properties of materials and compressive Strength evaluation by adding date seed as replacement of coarse aggregate only.

1. After performing the test, Strength is decreased by the addition of Date seeds with coarse aggregates same way density is decreased to make the concrete lightweight.

2. Most of the Date seeds were retaining on 5/16' and No. 4 sieves.

3. the workability of concrete is decreasing with increasing date seeds, this is due to Absorption of water by DS and increase in the surface area of coarser particles.

4. The density of date seeds is $843 \mathrm{~kg} / \mathrm{m}^{3}$ which is less than $1200 \mathrm{~kg} / \mathrm{m}^{3}$ (maximum density of lightweight CA).

This study also suggested following ideas for the future works :

1. On the basis of above conclusions additional research is suggested to check the outcome of date seed in concrete against durability and dimensional stability.

2. The DS seed should not be used in dry form, it must be poured in water for at least $48 \mathrm{hrs}$.

3. Since the addition of date seeds did not increase strength to concrete, it is suggested that these should be used in such parts of the structure where low or moderate strength is required.

\section{References}

[1] A. M. Neville and J. J. Brooks, Concrete technology, 2nd ed. New Jersey: PRentice Hall, 2010.

[2] B. Damodhara Reddy, S. Aruna Jyothy, and F. Shaik, "Experimental Analysis of the Use of 
Coconut Shell as Coarse Aggregate," 2014. Accessed: Jan. 14, 2021. [Online]. Available: www.iosrjournals.org.

[3] J. K. Prusty and S. K. Patro, "Properties of fresh and hardened concrete using agro-waste as partial replacement of coarse aggregate - A review," Constr. Build. Mater., vol. 82, pp. 101113, May 2015, doi: 10.1016/j.conbuildmat.2015.02.063.

[4] N. T. Singh, "Effective uses of Light Weight Concrete," J. Civ. Eng. Environ. Technol., vol. 3, no. 3, pp. 208-211, 2016.

[5] Z. Li, Advanced concrete technology. New Jersey: Hoboken, N.J. : Wiley, 2011.

[6] E. A. Olanipekun, K. O. Olusola, and O. Ata, "A comparative study of concrete properties using coconut shell and palm kernel shell as coarse aggregates," Build. Environ., vol. 41, pp. 297301, 2006, doi: 10.1016/j.buildenv.2005.01.029.

[7] A. Adefemi, M. H. Nensok, E. T. Ka'se, and I. A. Wuna, "Exploratory Study of Date Seed as Coarse Aggregate in Concrete Production," Civ. Environ. Res., vol. 3, no. 1, pp. 85-92, 2013, Accessed: Jan. 14, $2021 . \quad$ [Online]. Available: https://www.iiste.org/Journals/index.php/CER/article/view/3870.

[8] A. Afedemi, N. Adamu, and M. H. Nensok, "Durability Characteristics Of Concrete Produced With Date Seed As Light Weight," in West Africa Built Environment Research (Waber) Conference 24-26 July 2012, 2012, p. 217.

[9] M. Almograbi, "Durability study of lightweight concrete material made from date palma seeds (DPS)," in WIT Transactions on the Built Environment, Jul. 2010, vol. 112, pp. 69-75, doi: 10.2495/HPSM100071.

[10] S. M. Akib, M. D. Bhuva, and M. D. Pindoriya, "Exploratory Study On Partial Replacement Of Coarse Aggregate By Date Seed," Int. Res. J. Eng. Technol., vol. 7, no. 4, pp. 730-734, 2018.

[11] K. Muthusamy et al., "Exploratory study of rubber seed shell as partial coarse aggregate replacement in concrete," Res. J. Appl. Sci. Eng. Technol., vol. 7, no. 6, pp. 1013-1016, 2014, doi: $10.19026 /$ rjaset.7.380.

[12] C. C. T. Chao and R. R. Krueger, "The date palm (Phoenix dactylifera L.): Overview of biology, uses, and cultivation," in HortScience, Aug. 2007, vol. 42, no. 5, pp. 1077-1082, doi: 10.21273/hortsci.42.5.1077.

[13] D. C. L. Teo, M. A. Mannan, V. J. Kurian, and C. Ganapathy, "Lightweight concrete made from oil palm shell (OPS): Structural bond and durability properties," Build. Environ., vol. 42, no. 7, pp. 2614-2621, 2007.

[14] A. Aka, N. Adamu, and M. H. Nensok, "Durability Characteristics Of Concrete Produced With Date Seed As Light Weight," in West Africa Built Environment Research (Waber) Conference 24-26 July 2012, 2012, vol. 1, pp. 217-224.

[15] B. J. Olawuyi and O. K. O, "Compressive Strength of Volcanic Ash/Ordinary Portland Cement Laterized Concrete," Civ. Eng. Dimens., vol. 12, no. 1, pp. 23-28, 2010. 